\title{
Influence of Some Commercial Blends between the Imported Cotton and the Upper Egyptian Varieties on Technological Properties
}

\author{
Entsar A. F. Abdel-Ghaffar*; Gaber Y. M. Hammam**; Ahmad A. A. El-Hosary **; El-Saeed M. M. El- \\ Gedwy $^{* *}$ and Abd El-Based A. Hassan* \\ * Cotton Research Institute - Agricultural Research Center - Giza - Egypt. \\ ** Agronomy Department - Faculty of Agriculture - Benha University - Egypt. \\ Corresponding author: alsaeed.algedwy@fagr.bu.edu.eg
}

\begin{abstract}
The present study was carried out during 2016 season on the laboratory at Cotton Technology Research Division, Cotton Research Institute, Agricultural Research Center, Giza, Egypt, to investigate the effect of seven cotton materials, i.e. pure Egyptian cotton of Giza $90\left(\mathrm{~T}_{1}\right)$, pure Egyptian cotton of Giza $95\left(\mathrm{~T}_{2}\right)$, pure upland cotton $\left(\mathrm{T}_{3}\right)$, blend of $65 \%$ Giza $90+35 \%$ upland cotton $\left(\mathrm{T}_{4}\right)$, blend of $65 \%$ Giza $95+35 \%$ upland cotton $\left(\mathrm{T}_{5}\right)$, blend of $35 \%$ Giza $90+65 \%$ upland cotton $\left(\mathrm{T}_{6}\right)$ and blend of $35 \%$ Giza $95+65 \%$ upland cotton $\left(\mathrm{T}_{7}\right)$ and four yarn counts, i.e. 15's, 20's, 25's and 30's on fiber and yarn technological properties under using the new technique of the rotor open-end spinning system. The obvious results of this investigation can be summarized as follows:

The differences between the studied seven cotton materials in mean values of all fiber and yarn technological properties were significant. Pure Egyptian cotton of Giza 95 significantly recorded the highest mean values for upper half mean length $(\mathrm{mm})$, uniformity $(\%)$, fiber strength $(\mathrm{g} / \mathrm{tex})$, maturity, maturity ratio $(\%)$, reflectance degree, No. of convolution/cm and yarn strength vice versa, it gave the lowest mean values of fiber elongation (\%), fineness (mill/tex), diameter $(\mu)$, No. of reversal/cm, evenness/100 m, No. of neps/100 m, No. of thin places/100 m, No. of thick places/100 m and hairiness. While, Pure Egyptian cotton of Giza 90 significantly recorded the maximum mean value of yellow-ness, however it gave the lowest mean values of short fiber index $(\%)$ and micronaire value. Meanwhile, the maximum mean values of short fiber index (\%), fiber elongation (\%), micronaire value, fineness (mill/tex), diameter $(\mu)$, No. of reversal/cm, evenness $/ 100 \mathrm{~m}$, No. of neps/100 m, No. of thin places $/ 100 \mathrm{~m}$, No. of thick places $/ 100 \mathrm{~m}$ and hairiness as well as, the minimum mean values of upper half mean length $(\mathrm{mm})$, uniformity $(\%)$, fiber strength (g/tex), maturity ratio (\%), yellow-ness and No. of convolution $/ \mathrm{cm}$ which were obtained from pure upland cotton. But, no significant differences were detected between $T_{1}$ and $T_{2}$ as well as between $T_{4}$ and $T_{5}$ also between $T_{6}$ and $T_{7}$ were no significant on allmost fiber and yarn technological properties.

Increasing yarn counts from 15's, 20's and 25's to 30's caused significant increments in mean values of evenness/100 m, No. of neps/100 m, No. of thin places/100 m and No. of thick places/100 m. On the other hand, mean values of yarn strength and hairiness were significantly decreased with increasing yarn counts. The yarns produced at yarn count of 30's significantly recorded the maximum mean values of evenness/100 m, No. of neps $/ 100 \mathrm{~m}$, No. of thin places $/ 100 \mathrm{~m}$ and No. of thick places $/ 100 \mathrm{~m}$ as well as, gave the lowest mean values of yarn strength and hairiness. Meanwhile, the maximum mean values of yarn strength and hairiness as well as, the lowest mean values of evenness/100 m, No. of neps/100 m, No. of thin places/100 m and No. of thick places/100 $\mathrm{m}$ which were obtained from yarn count of 15 's.

Significant effect of the interaction between seven cotton materials and four yarn obtained for mean values of yarn strength, No. of neps/100 m, No. of thin places/100 m and No. of thick places/100 m. Meanwhile, mean values of evenness $/ 100 \mathrm{~m}$ and hairiness were not significantly affected by the interaction between cotton materials and yarn counts. The greatest mean value of yarn strength as well as, the lowest mean values of No. of neps/100 $\mathrm{m}$, No. of thin places/100 $\mathrm{m}$ and No. of thick places/100 m which were obtained from pure Egyptian cotton of Giza 95 at yarn count of 15's. Meanwhile, The highest mean values of No. of neps/100 m, No. of thin places/100 $\mathrm{m}$ and No. of thick places/100 $\mathrm{m}$ as well as the lowest of mean value of yarn strength which were obtained from pure upland cotton yarn count of 30's.
\end{abstract}

Keywords: Egyptian cotton, upland cotton, yarn counts, fiber and yarn technological properties

\section{Introduction}

Cotton is the most widely used fiber crop in the textile industry in the world. It plays an exceptionally important role in the national economy of the leading cotton growing countries such as the United States of America, Russia, China, India and Pakistan. In Egypt cotton is an important fiber and edible oil crop. The total area cultivated with cotton has been decreased in Egypt in recent years due to the need for growing more food crops as well as, increasing costs of production (Abdel-Samad et al. 2017). Combined with the low farm gate price, have made cotton less profitable to the farmer. For the above reasons, the ultimate aim of cotton production programs is to increase the yield capacity as well as fiber and yarn technological 
properties. As a result of the great increase of population and consumption of both raw cotton and fabrics, Egypt can export Egyptian cottons of high quality and price and import American upland cottons of low quality and price to produce blended coarse yarns. Blending of extremely different cottons in their quality and price was investigated as a possible way of economical using these cottons in the blend form. In an effort to show the merits of recalculated blending of cotton a systematic study of blends containing varying amounts of some American upland and Egyptian cotton varieties have been made.

Several investigators showed that materials of cotton and blending of cotton materials were significant differed in mean values of all fiber technological properties, i.e. upper half mean length, uniformity $\%$, short fiber index, strength, elongation $\%$, micronaire value, maturity, maturity ratio, color attributes (reflectance degree and yellow-ness), fineness, diameter, No. of convolution and No. of reversal as well as yarn technological properties, i.e. strength, evenness, No. of neps, No. of thin places, No. of thick places and hairiness (Mohammed and ElSayed 2002; Mabrouk and Nour 2005; Hassan 2006; Marinus 2007; Ureyen and Kadagla 2007; Abdel-Fattah 2008; El-Sayed 2009; Pramanik and Patil 2009; Taher et al. 2009; Ahmed et al. 2014; Hager and Hassan 2016; Rizk et al. 2016; AbdelKhalik et al. 2017; Abdel-Samad et al. 2017; Tolba 2017 and El-Gedwy et al. 2018).

Significantly increases in allmost yarn technological properties, i.e. evenness, No. of neps, No. of thin places and No. of thick places with increasing yarn counts. On the other hand, yarn strength and hairiness were significantly decreased by increasing yarn counts (Marinus 2007; Ureyen and Kadagla 2007; Taher et al. 2009 Hager and Hassan 2016; Rizk et al. 2016; Abdel-Khalik et al. 2017 and Tolba 2017).

The interaction between cotton materials and yarn counts were significant on mean values of yarn technological properties, i.e. strength, evenness, No. of neps, No. of thin places, No. of thick places and hairiness (Marinus 2007; Ureyen and Kadagla 2007; Taher et al. 2009; Hager and Hassan 2016; Rizk et al. 2016 Abdel-Khalik et al. 2017 and Tolba 2017).

The aim of this study was to investigate the possibility of blends of some Egyptian cotton varieties and upland cotton under different yarn counts to reduce the cost of production and to be economical for the popular fibers.

\section{Materials and Methods}

The present study was carried out during 2016 season on the laboratory at Cotton Technology Research Division, Cotton Research Institute, Agricultural Research Center, Giza, Egypt. The aim of this study was to investigate the effect of seven cotton materials, i.e. $100 \%$ Giza 90, $100 \%$ Giza 95, $100 \%$ upland cotton and blends of $65 \%$ Giza $90+35 \%$ upland cotton, $65 \%$ Giza $95+35 \%$ upland cotton, 35 $\%$ Giza $90+65 \%$ upland cotton and $35 \%$ Giza $95+$ $65 \%$ upland cotton and four yarn counts, i.e. 15's, 20 's, 25's and 30's on fiber and yarn technological properties using the new technique of the rotor openend spinning system. It is well known that, large amounts of cotton fiber wastes annually produced by the Egyptian spinning factory Masr Helwan-HalwanGiza.

The blends were carried out according to the standard method designated by Hollen and Saddlers (1973). The blends method and the desired amounts of each cotton fibers were weighted and a layer of each was spread over the preceding layer to build up a sandwich composed of many layers. Sections were then composed of many layers. Sections were then taken through the sandwich and carefully mixed.

\section{Apparatus and machines:}

- Conventional carding machine: The source sample of each cotton materials was carded using conventional carding machine to produce 0.26 Hank Slivers.

- The combing process: the combing process was carried out on the second card slivers for the aim of producing finer yarns as a result of separating the short fibers from the longer ones, as well as trash content and neps

- Autocoro 288 Open-End rotor spinning machine was used to perform the spinning process for all studied samples.

The specifications of this machine were as follows:

- Rotor speed: 100.000 r.p.m. (Cotton type rotor).

- Opening roller speed: 8.200 r.p.m. (Cotton type opening roller).

- Rotor diameter: $31 \mathrm{~mm}$.

Yarn count and twist multipliers studied:-

Each cotton fiber material was spun into four carded yarn counts, i.e. 15, 20, 25 and 30's, using twist multipliers 4 . In another words, each cotton material was subjected to 7 treatments, which are the combination between four yarn counts. All these treatments were conducted at the Spinning Research Section, Cotton Research Institute, Agricultural Research Center, Giza.

\section{Studied traits:}

Fiber technological properties:

Different huge blending weight $1 \mathrm{~kg}$ were prepared from each raw material used and after homogenous mixing $200 \mathrm{~g}$ was taken to determine fiber technological properties were determined at Cotton Technology Research Division, Cotton Research Institute, Giza, Egypt, at a constant relative humidity $65 \%( \pm 2)$ and temperature $21 \mathrm{C}^{\mathrm{O}}( \pm 2)$. High Volume 
Instrument (H.V.I.) instrument system was used to determine: upper half mean length $(\mathrm{mm})$, uniformity $(\%)$, short fiber index $(\%)$, fiber strength $(\mathrm{g} / \mathrm{tex})$, fiber elongation $(\%)$, micronaire value, maturity, maturity ratio (\%) and fiber color attributes, i.e. fiber reflectance $(\mathrm{Rd} \%)$ and fiber yellowness degree $\left({ }^{+} \mathrm{b}\right)$ according to (A.S.T.M., 1986 D:4605). Meanwhile, fiber fineness (mill/tex) was determined by using Micromat tester according to (A.S.T.M., 1998 D381879). While, fiber diameter $(\mu)$, No. of convolution $/ \mathrm{cm}$ and No. of reversal/cm were processed at Fiber Structure Lab. Cotton Res. Ins., Agric. Res. center, Giza, Egypt, according to methods described by Hequet et al. (2006).

\section{Yarn technological properties:}

Yarn strength (Lea product) was determined by testing the skein strength on the Good Brand lea tester to estimate the lea strength (Lea product) in pounds (A.S.T.M., 1967 D-1578) the Broken leas were weighted by a Souter Al-fered Balance (A.S.T.M., 1967 D-1907) to estimate its actual count. The lea breaking strength was corrected according to the actual count. Lea product was the nominal count estimate from the following formula:

\section{Lea product $=$ Corrected breaking load in pounds} $\mathrm{x}$ nominal count.

Coefficient of variation of the yarn evenness (C.V.\%), No. of neps $/ 100 \mathrm{~m}$, No. of thin places $/ 100 \mathrm{~m}$, No. of thick places $/ 100 \mathrm{~m}$ and hairiness of the yarn were measured by the Uster Evenness Tester III as described by the designation of the (A.S.T.M., 1984 D-2256).

\section{Statistical analysis:}

The experiment was carried out using the complete randomized design in three replications. The analysis of variance was carried out according to the procedure described by Gomez and Gomez (1984). Data were statistically analyzed according to using the MSTATC Statistical Software Package (Michigan State University, 1983). Where the F-test showed significant differences among mean of treatments, the least significant difference (L.S.D.) test at 0.05 level was used to compare between means.

\section{Results and Discussion}

\section{Fiber technological properties:}

Results presented in Tables 1 and 2 revealed that the differences between the studied seven cotton materials, i.e. $100 \%$ Giza 90, $100 \%$ Giza 95, $100 \%$ upland cotton and blends of $65 \%$ Giza $90+35 \%$ upland cotton, $65 \%$ Giza $95+35 \%$ upland cotton, 35 $\%$ Giza $90+65 \%$ upland cotton and $35 \%$ Giza $95+$ $65 \%$ upland cotton in mean values of all fiber technological properties, i.e. upper half mean length, uniformity $\%$, short fiber index, fiber strength, fiber elongation $\%$, micronaire value, maturity, maturity ratio, color attributes (reflectance degree and yellowness), fineness, diameter, No. of convolution/ $\mathrm{cm}$ and No. of reversal $/ \mathrm{cm}$ were significant. But, the difference between fibers which produced from $100 \%$ Giza 90 and $100 \%$ Giza 95 as well as between blends of $65 \%$ Giza $90+35 \%$ upland cotton and $65 \%$ Giza $95+35 \%$ upland cotton also between blends of $35 \%$ Giza $95+65 \%$ upland cotton and $35 \%$ Giza $90+65$ $\%$ upland cotton were no significant on allmost fiber technological properties. The fibers which obtained from pure Egyptian cotton of Giza 95 significantly recorded the greatest mean values of upper half mean length $(30.03 \mathrm{~mm})$, uniformity $(85.03 \%)$, fiber strength (37.70 g/tex), maturity (0.96), maturity ratio $(78.97 \%)$, reflectance degree $(66.83)$ and No. of convolution/cm (35.70), vice versa, significantly gave the lowest mean values of fiber elongation $(8.30 \%)$, fineness (146.83 milltex), diameter $(14.13 \mu)$ and No. of reversal/cm (7.3). The seven tested of cotton materials could be arranged in a descending order with regard to the mean values of fiber strength (g/tex) as follows, $100 \%$ Giza 95 (37.70 g/tex), $100 \%$ Giza 90 (36.53 g/tex), blend of $65 \%$ Giza $95+35 \%$ upland cotton $(35.00 \mathrm{~g} / \mathrm{tex})$, blend of $65 \%$ Giza $90+35 \%$ upland cotton (33.90 g/tex), blend of $35 \%$ Giza $95+$ $65 \%$ upland cotton $(31.60 \mathrm{~g} / \mathrm{tex})$, blend of $35 \%$ Giza $90+65 \%$ upland cotton $(31.13 \mathrm{~g} / \mathrm{tex})$ then $100 \%$ upland cotton $(28.40 \mathrm{~g} / \mathrm{tex})$. However, the fibers which obtained from pure Egyptian cotton of Giza 90 significantly recorded the maximum mean value of yellow-ness (12.00) as well as, significantly gave the lowest mean values of short fiber index $(8.77 \%)$ and micronaire value (4.07). Meanwhile, the fibers which obtained from pure upland cotton significantly gave the maximum mean values of short fiber index (15.07 $\%)$, fiber elongation $(9.5 \%)$, micronaire value (5.03), fineness $(185.57$ milltex $)$, diameter $(17.53 \mu)$ and No. of reversal/cm (8.53) and significantly produced the minimum mean values of upper half mean length (28.33 mm), uniformity (74.07\%), fiber strength $(28.40 \mathrm{~g} /$ tex $)$ maturity ratio $(75.00 \%)$, yellow-ness (9.60) and No. of convolution/cm (29.07).The seven tested of cotton materials could be arranged in an ascending order with regard to the mean values of fiber fineness (g/tex) as follows, $100 \%$ Giza 95 (146.83 mill/tex), $100 \%$ Giza 90 (155.53 mill/tex), blend of 65 $\%$ Giza $95+35 \%$ upland cotton (160.20 mill/tex), blend of $65 \%$ Giza $90+35 \%$ upland cotton $(166.47$ mill/tex), blend of $35 \%$ Giza $95+65 \%$ upland cotton (173.13 mill/tex), blend of $35 \%$ Giza $90+65 \%$ upland cotton (175.53 mill/tex) then $100 \%$ upland cotton (185.57 mill/tex). These differences may be due to the genetic differences between the three cotton varieties. These results are in harmony with those reported by Mohammed and El-Sayed 2002; Mabrouk and Nour 2005; Hassan 2006; Marinus 2007; Ureyen and Kadagla 2007; Abdel-Fattah 
2008; El-Sayed 2009; Pramanik and Patil 2009; Taher et al. 2009; Ahmed et al. 2014; Hager and Hassan 2016; Rizk et al. 2016; Abdel-Khalik et al.
2017; Abdel-Samad et al. 2017; Tolba 2017 and ElGedwy et al. 2018 they showed that cotton materials markedly varied in fiber technological properties.

Table 1. Effect of cotton materials on fiber technological properties and color attribute as estimated by High Volume Instrument (H.V.I) daring 2016 season

\begin{tabular}{|c|c|c|c|c|c|c|c|c|c|c|}
\hline & \multirow[b]{2}{*}{ 胥 } & \multirow[b]{2}{*}{ 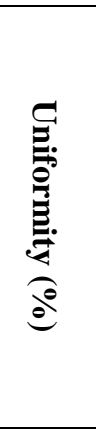 } & \multirow[b]{2}{*}{ 公高 } & \multirow[b]{2}{*}{ 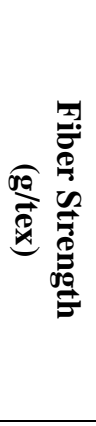 } & \multirow[b]{2}{*}{ 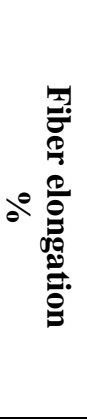 } & \multirow[b]{2}{*}{ 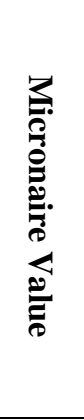 } & \multirow[b]{2}{*}{ } & \multirow[b]{2}{*}{ 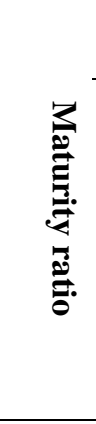 } & \multicolumn{2}{|c|}{$\begin{array}{c}\text { Color } \\
\text { attributes }\end{array}$} \\
\hline Character & & & & & & & & & 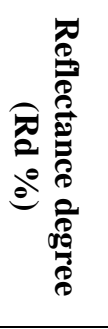 & 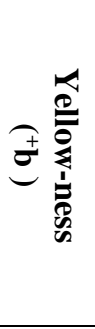 \\
\hline Pure Egyptian cotton of Giza 90 & 29.47 & 84.07 & 8.77 & 36.53 & 8.47 & 4.07 & 0.95 & 76.00 & 64.23 & 12.00 \\
\hline Pure Egyptian cotton Giza 95 & 30.03 & 85.03 & 8.80 & 37.70 & 8.30 & 4.27 & 0.96 & 78.97 & 66.83 & 11.67 \\
\hline Pure Upland cotton & 28.33 & 74.07 & 15.07 & 28.40 & 9.50 & 5.03 & 0.83 & 75.00 & 63.60 & 9.60 \\
\hline Blend of $65 \%$ Giza $90+35 \%$ upland cotton & 29.07 & 80.97 & 10.07 & 33.90 & 8.47 & 4.07 & 0.91 & 75.50 & 63.27 & 11.03 \\
\hline Blend of $65 \%$ Giza $95+35 \%$ upland cotton & 29.47 & 81.10 & 10.87 & 35.00 & 8.50 & 4.60 & 0.91 & 77.70 & 65.53 & 11.07 \\
\hline Blend of $35 \%$ Giza $90+65 \%$ upland cotton & 28.80 & 77.50 & 12.47 & 31.13 & 8.90 & 4.43 & 0.82 & 75.37 & 63.53 & 10.27 \\
\hline Blend of $35 \%$ Giza $95+65 \%$ upland cotton & 28.77 & 79.87 & 12.73 & 31.60 & 8.67 & 4.80 & 0.87 & 77.50 & 65.13 & 10.20 \\
\hline L. S. D. at $5 \%$ & 0.61 & $\mathbf{0 . 8 8}$ & 0.76 & 1.26 & 0.38 & 0.47 & 0.09 & 1.25 & 1.13 & 0.80 \\
\hline
\end{tabular}

Table 2. Effect of cotton materials on fiber technological properties as estimated by image analysis during 2016 season

\begin{tabular}{|c|c|c|c|c|}
\hline Character & $\begin{array}{l}\text { Fineness } \\
\text { (mille tex) }\end{array}$ & $\begin{array}{c}\text { Diameter } \\
(\mu)\end{array}$ & $\begin{array}{c}\text { Convolutio } \\
\text { n No/cm }\end{array}$ & $\begin{array}{c}\text { Reversal } \\
\text { No/cm }\end{array}$ \\
\hline Pure Egyptian cotton of Giza 90 & 155.53 & 15.07 & 33.20 & 7.60 \\
\hline Pure Egyptian cotton Giza 95 & 146.83 & 14.13 & 35.70 & 7.30 \\
\hline Pure Upland cotton & 185.57 & 17.53 & 29.07 & 8.53 \\
\hline Blend of $65 \%$ Giza $90+35 \%$ upland cotton & 166.47 & 15.90 & 31.83 & 8.00 \\
\hline Blend of $65 \%$ Giza $95+35 \%$ upland cotton & 160.20 & 15.30 & 33.70 & 7.73 \\
\hline Blend of $35 \%$ Giza $90+65 \%$ upland cotton & 175.53 & 16.50 & 30.47 & 8.37 \\
\hline Blend of $35 \%$ Giza $95+65 \%$ upland cotton & 173.13 & 16.17 & 31.43 & 8.20 \\
\hline L.S.D at $5 \%$ & 9.21 & $\mathbf{0 . 8 6}$ & 1.64 & 0.34 \\
\hline
\end{tabular}

\section{Yarn technological properties:}

\section{Effect of cotton materials:}

Results presented in Table 3 showed that mean values of all yarn technological properties, i.e. yarn strength, evenness/100 m (c.v. \%), No. of neps/100 m, No. of thin places $/ 100 \mathrm{~m}$, No. of thick places/100 m and hairiness were significant differences with the studied seven cotton materials, i.e. $100 \%$ Giza 90, 100 $\%$ Giza 95, $100 \%$ upland cotton and blends of $65 \%$ Giza $90+35 \%$ upland cotton, $65 \%$ Giza $95+35 \%$ upland cotton, $35 \%$ Giza $90+65 \%$ upland cotton and $35 \%$ Giza $95+65 \%$ upland cotton. But, no significant difference was detected between $100 \%$ Giza 90 and
$100 \%$ Giza 95 as well as between blends of $65 \%$ Giza $90+35 \%$ upland cotton and $65 \%$ Giza $95+35 \%$ upland cotton also between blends of $35 \%$ Giza $95+$ $65 \%$ upland cotton and $35 \%$ Giza $90+65 \%$ upland cotton were no significant on allmost yarn technological properties. The maximum mean value of yarn strength (2544.0) as well as the lowest mean values of evenness/100 m (12.78\%), No. of neps/100 $\mathrm{m}$ (76.1 neps), No. of thin places/100 m (16.4 thin places), No. of thick places/100 m (10.1 thick places) and hairiness (4.66) were obtained from yarns which produced from pure Egyptian cotton of Giza 95. The yarns which was obtained from pure upland cotton significantly gave the highest mean values of evenness/100 m (15.09\%), No. of neps/100 m (105.5 
neps), No. of thin places/100 m (25.3 thin places), No. of thick places/100 $\mathrm{m}$ (19.8 thick places) and hairiness (6.15). The seven tested of cotton materials could be arranged in an ascending order with regard to the mean values of No. of neps/100 m as follows, $100 \%$ Giza 95 (76.1 neps), $100 \%$ Giza 90 (84.9 neps), blend of 65 $\%$ Giza $95+35 \%$ upland cotton (86.3 neps), blend of $65 \%$ Giza $90+35 \%$ upland cotton (91.9 neps), blend of $35 \%$ Giza $95+65 \%$ upland cotton (95.5 neps), blend of $35 \%$ Giza $90+65 \%$ upland cotton $(98.2$ neps) then $100 \%$ upland cotton (105.5 neps). The results which reported by Mohammed and El-Sayed 2002; Mabrouk and Nour 2005; Hassan 2006; Marinus 2007; Ureyen and Kadagla 2007; AbdelFattah 2008; El-Sayed 2009; Pramanik and Patil 2009; Taher et al. 2009; Ahmed et al. 2014; Hager and Hassan 2016; Rizk et al. 2016; Abdel-Khalik et al. 2017 and Tolba, 2017 they found that materials of cotton markedly varied in yarn technological properties.

\section{Effect of yarn counts:}

Results in Table 3 indicated that increasing yarn counts from 15's, 20's and 25's to 30's caused significant increments in mean values of evenness $/ 100$ $\mathrm{m}$, No. of neps $/ 100 \mathrm{~m}$, No. of thin places/100 m and No. of thick places $/ 100 \mathrm{~m}$. On the other hand, mean values of yarn strength and hairiness were significantly decreased with increasing yarn counts. The yarns produced at yarn count of 30's significantly recorded the maximum mean values of evenness $/ 100$ $\mathrm{m}(15.37 \%)$, No. of neps/100 m (106.8 neps), No. of thin places/100 $\mathrm{m}$ (26.7 thin places) and No. of thick places $/ 100 \mathrm{~m}$ (22.9 thick places) as well as, gave the lowest mean values of yarn strength (2326.4) and hairiness (4.74). The maximum mean values of yarn strength (2620.7) and hairiness (6.64) as well as, the lowest mean values of evenness/100 m (12.47\%), No. of neps/100 m (76.8 neps), No. of thin places/100 m (14.5 thin places) and No. of thick places/100 m (7.8 thick places) which were obtained from yarn count of 15 's. The yarns which obtained from yarn counts of 20's, 25's and 30's caused a significant decreases over the yarn count of 15 's by $3.87,6.54$ and $11.23 \%$ for yarn strength and 14.61, 21.54 and $28.61 \%$, for hairiness, respectively. Increasing yarn count from 15 's to 20's, 25's and 30's caused significant increases by $4.73,15.88$ and $23.26 \%$ for evenness $/ 100 \mathrm{~m} ; 11.85$, 23.96 and $39.06 \%$ for No. of neps/100 m; 40.69, 64.83 and $84.14 \%$ for No. of thin places in addition to 66.67 , 133.33 and $193.59 \%$ for No. of thick places, respectively. These results may be due to the yarn cross section satisfactory spinning if the member is below the acceptable level increase in end breakage, irregularity and loss in yarn strength become prohibiting. Similar observations have been showed by Marinus 2007; Ureyen and Kadagla 2007; Taher et al. 2009; Hager and Hassan 2016; Rizk et al. 2016; Abdel-Khal*ik et al. 2017 and Tolba 2017.

\section{Interaction effect:}

Significant effect of the interaction between seven cotton materials (100\% Giza 90, $100 \%$ Giza 95, 100 $\%$ upland cotton and blends of $65 \%$ Giza $90+35 \%$ upland cotton, $65 \%$ Giza $95+35 \%$ upland cotton, 35 $\%$ Giza $90+65 \%$ upland cotton and $35 \%$ Giza $95+$ $65 \%$ upland cotton) and four yarn counts (15's, 20's, 25 's and 30's) obtained for mean values of yarn strength, No. of neps $/ 100 \mathrm{~m}$, No. of thin places $/ 100 \mathrm{~m}$ and No. of thick places $/ 100 \mathrm{~m}$. Meanwhile, mean values of evenness $/ 100 \mathrm{~m}$ and hairiness were not significantly affected by the interaction between cotton materials and yarn counts (Table 3 ). Results indicated that pure upland cotton gave the highest mean values for No. of neps $/ 100 \mathrm{~m}$, No. of thin places/100 $\mathrm{m}$ and No. of thick places/100 $\mathrm{m}$ under all yarn counts. Whereas, pure Egyptian cotton of Giza 95 gave the lowest mean values under all yarn counts levels. Also, yarn count of 30's gave the greatest mean values for these traits under all cotton materials. On the other hand, the lowest mean values for these traits were obtained from yarn count of 15 's under all cotton materials. The greatest mean value of yarn strength (2695) vice versa, the lowest mean values of No. of neps/100 m (60.3 neps), No. of thin places/100 m (10.0 thin places) and No. of thick places/100 m (5.3 thick places) which were obtained from pure Egyptian cotton of Giza 95 at yarn count of 15's. Meanwhile, The highest mean values of No. of neps/100 m (128.0 neps), No. of thin places/100 m (31.0 thin places) and No. of thick places/100 m (28.3 thick places) as well as the lowest of mean value of yarn strength (2205) which were obtained from pure upland cotton at yarn count of 30's. These results are in agreement with those obtained by Marinus 2007; Ureyen and Kadagla 2007; Taher et al. 2009; Hager and Hassan 2016; Rizk et al. 2016; Abdel-Khalik et al. 2017 and Tolba 2017 they found that yarn technological properties were significantly affected by the interaction between cotton materials and yarn counts. 
Table 3. Effect of cotton materials and yarn counts and their interaction on yarn technological properties/100 m in the produced yarns during 2016 season

\begin{tabular}{|c|c|c|c|c|c|c|c|}
\hline Treatment & Trait & strength & $\begin{array}{l}\text { Evenness } \\
\text { (c.v.) }\end{array}$ & $\begin{array}{c}\text { No. of } \\
\text { neps }\end{array}$ & $\begin{array}{c}\text { No. of } \\
\text { thin } \\
\text { places }\end{array}$ & $\begin{array}{c}\text { No. of } \\
\text { thick } \\
\text { places }\end{array}$ & Hairiness \\
\hline \multicolumn{8}{|l|}{ Cotton material } \\
\hline \multicolumn{2}{|l|}{ Pure Egyptian cotton of Giza 90} & 2510.0 & 13.05 & 84.9 & 20.1 & 14.3 & 5.56 \\
\hline \multicolumn{2}{|l|}{ Pure Egyptian cotton Giza 95} & 2555.0 & 12.78 & 76.1 & 16.4 & 10.1 & 4.66 \\
\hline \multicolumn{2}{|l|}{ Pure Upland cotton } & 2441.3 & 15.09 & 105.5 & 25.3 & 19.8 & 6.15 \\
\hline \multicolumn{2}{|c|}{ Blend of $65 \%$ Giza $90+35 \%$ upland cotton } & 2488.8 & 13.74 & 91.9 & 22.2 & 16.3 & 5.82 \\
\hline \multicolumn{2}{|c|}{ Blend of $65 \%$ Giza $95+35 \%$ upland cotton } & 2485.0 & 13.55 & 86.3 & 19.7 & 13.2 & 5.16 \\
\hline \multicolumn{2}{|c|}{ Blend of $35 \%$ Giza $90+65 \%$ upland cotton } & 2403.8 & 14.37 & 98.2 & 23.4 & 18.2 & 5.94 \\
\hline \multicolumn{2}{|c|}{ Blend of $35 \%$ Giza $95+65 \%$ upland cotton } & 2468.8 & 14.29 & 95.5 & 22.6 & 16.5 & 5.67 \\
\hline \multicolumn{2}{|c|}{ L.S.D. at 5\% } & 54.2 & 1.15 & 3.6 & 1.9 & 2.5 & $\mathbf{0 . 3 0}$ \\
\hline \multicolumn{8}{|l|}{ Yarn count } \\
\hline \multicolumn{2}{|l|}{15 's } & 2620.7 & 12.47 & 76.8 & 14.5 & 7.8 & 6.64 \\
\hline \multicolumn{2}{|l|}{ 20's } & 2519.3 & 13.06 & 85.9 & 20.4 & 13.0 & 5.67 \\
\hline \multicolumn{2}{|l|}{25 's } & 2449.3 & 14.45 & 95.2 & 23.9 & 18.2 & 5.21 \\
\hline \multicolumn{2}{|l|}{ 30's } & 2326.4 & 15.37 & 106.8 & 26.7 & 22.9 & 4.74 \\
\hline \multicolumn{2}{|c|}{ L.S.D. at $5 \%$} & 41.0 & $\mathbf{0 . 8 7}$ & 2.7 & 1.4 & 1.9 & 0.23 \\
\hline \\
\hline \multicolumn{8}{|c|}{ 15's 2650} \\
\hline \multirow{4}{*}{ Pure Egyptian cotton of Giza 90} & $20 ’ s$ & 2560 & 12.31 & 82.0 & 18.0 & 11.0 & 5.70 \\
\hline & 25 's & 2480 & 13.83 & 88.3 & 22.0 & 18.0 & 4.97 \\
\hline & 30 's & 2350 & 14.40 & 93.0 & 25.3 & 21.0 & 4.77 \\
\hline & 15 's & 2695 & 11.25 & 60.3 & 10.0 & 5.3 & 5.23 \\
\hline \multirow{5}{*}{ Pure Egyptian cotton of Giza 95} & 20 's & 2610 & 12.21 & 75.3 & 15.7 & 7.7 & 4.77 \\
\hline & 25 's & 2510 & 13.50 & 80.0 & 19.0 & 11.0 & 4.57 \\
\hline & $30 ’ s$ & 2405 & 14.17 & 88.7 & 21.0 & 16.3 & 4.07 \\
\hline & 15 's & 2580 & 13.89 & 88.7 & 17.0 & 10.0 & 7.50 \\
\hline & 20 's & 2450 & 14.20 & 95.3 & 25.0 & 17.7 & 6.20 \\
\hline \multirow{3}{*}{ Pure upland cotton } & 25 's & 2530 & 15.49 & 110.0 & 28.0 & 23.0 & 5.77 \\
\hline & 30 ’s & 2205 & 16.79 & 128.0 & 31.0 & 28.3 & 5.13 \\
\hline & $15^{\prime} \mathrm{s}$ & 2650 & 12.34 & 80.3 & 16.7 & 8.0 & 7.20 \\
\hline \multirow{4}{*}{$\begin{array}{l}\text { Blend of } 65 \% \text { Giza } 90+ \\
35 \% \text { upland cotton }\end{array}$} & 20 's & 2520 & 12.93 & 86.7 & 20.3 & 14.0 & 5.87 \\
\hline & 25 's & 2420 & 14.42 & 95.7 & 24.0 & 20.0 & 5.30 \\
\hline & 30 's & 2365 & 15.28 & 104.7 & 27.7 & 23.3 & 4.90 \\
\hline & 15 's & 2650 & 12.09 & 69.0 & 11.7 & 7.3 & 5.97 \\
\hline \multirow{4}{*}{$\begin{array}{l}\text { Blend of } 65 \% \text { Giza } 95+ \\
35 \% \text { upland cotton }\end{array}$} & 20 's & 2505 & 12.83 & 83.0 & 19.0 & 10.3 & 5.37 \\
\hline & 25 's & 2455 & 14.16 & 90.0 & 23.0 & 15.0 & 4.90 \\
\hline & 30 's & 2330 & 15.10 & 103.0 & 25.0 & 20.3 & 4.40 \\
\hline & 15 's & 2500 & 13.10 & 84.0 & 16.0 & 8.7 & 7.07 \\
\hline Blend of $35 \%$ Giza $90+$ & 20 's & 2490 & 13.51 & 90.3 & 23.0 & 15.7 & 6.00 \\
\hline & 25 's & 2370 & 14.91 & 103.0 & 26.0 & 21.0 & 5.50 \\
\hline & 30 's & 2255 & 15.95 & 115.3 & 28.7 & 27.3 & 5.17 \\
\hline & 15 's & 2620 & 12.95 & 78.7 & 15.0 & 8.3 & 6.70 \\
\hline Blend of $35 \%$ Giza 95 & 20 ’s & 2500 & 13.46 & 89.0 & 22.0 & 14.3 & 5.77 \\
\hline + $65 \%$ upland cotton & 25 's & 2380 & 14.85 & 99.7 & 25.3 & 19.3 & 5.43 \\
\hline & 30 's & 2375 & 15.89 & 114.7 & 28.0 & 24.0 & 4.77 \\
\hline L.S.D. at $5 \%$ & & 108 & N.S. & 7.1 & 3.7 & 5.0 & N.S. \\
\hline
\end{tabular}




\section{References}

A. S. T. M. (1967). Standards on textile, (D-1578 \& D-1907). Philadelphia, USA.

A. S. T. M. (1984). Standards on textile, (D-1445 \& D-2256). Philadelphia, USA.

A. S. T. M. (1986). Standards on textile, (D-3818 \& D-4605). Philadelphia, USA.

A. S. T. M. (1998). Standards on textile, (D-381879) Philadelphia, USA.

Abdel-Fattah, H. S. (2008). Effect of variety, location and seed cotton level on the fiber quality index of the Egyptian cotton. Ph.D. Thesis, Fac. Agric., Saba Bacha Alex. Univ., Egypt.

Abdel-Khalik, F. S.; E. M. Shoker; S. A. H. Allam; E. M. M. El-Gedwy and A. A. Hassan (2017). Production of low priced, medium and coarse yarns using rotor spinning system. Egypt. J. Appl. Sci., 32 (1): 11-24.

Abdel-Samad, H. S.; A. A. El Hosary; E. M. H. Shokr; M. E. El-Badawy; A. E. M. Eissa and A. A. A. El Hosary (2017). Selecting high yield and quality cotton genotypes using phenotypic and genotypic stability statistics. Egypt. J. Plant Breed., 21 (5): 642-653.

Ahmed, H. S. A.; A. A. Hassan and O. D. M. Nour (2014). Studies on the relative contribution of fiber properties in yarn variation strength in some Egyptian cotton variety and promising. Egypt. J. Appl. Sci., 29 (12 b): 697-708.

El-Gedwy, E. M. M.; A. E. M. Gadallh and R. M. Abdel-Twab (2018). Response of some Egyptian cotton cultivars to foliar spray by some microelements. Annals of Agric. Sci., Moshtohor, 56 (4):

El-Sayed, E. R. (2009). Effect of count and twist multiplier on mechanical properties of single yarn on some Egyptian cotton varieties. M. Sc. Thesis, Fac. Agric., Cairo Univ., Egypt.

Gomez, K. A. and A. A. Gomez (1984). Statistical Procedures for Agricultural Research. $2^{\text {nd }}$ ed. John Wiley and Sons, NY, U.S.A.

Hager, M. A and A. A. Hassan (2016). Use of correlation and regression analysis in estimating relative importance of fiber properties affecting yarn hairiness in some Egyptian cotton genotypes. Int. J. adv. Res., 4 (8):1274-1284.
Hassan, A. A. (2006). Production of low priced medium coarse yarn with acceptable quality using rotor spinning system. Ph. D. Thesis, Fac. Agric., Al-Azhar Univ., Egypt.

Hequet, E. F.; B. Wyatt; N. Abidi and D. P. Thibodeaux (2006). Creation of a set of reference material for cotton fiber maturity measurements. Textile Res. J., 76 (7): 576- 586.

Hollen, N, and J. Saddlers (1973). Textile Macmillan co., New-York.

Mabrouk, K. I. K. and M. D. O. Nour (2005). Possibility of spinning and blending the waste of carding and combing for coarse count on the Open-End rotor spinning. Egypt Agric. Res., 83 (3): 1305-1315.

Marinus, H. J. (2007). Blending could and value to long staple upland varieties, Textile and fiber technology. Australian cotton Grower, 34-38.

Michigan State University (1983). MSTAT-C: Micro-computer Statistical Program, Version 2. Michigan State University, East Lansing.

Mohammed, A. M. and M. A. M. El-Sayed (2002). Processing of wastes and low quality cottons on the open -end rotor spinning. Agric. Res. J., 80 (4): 1709-1718.

Pramanik, P. and M. V. Patil (2009). Physical Characteristics of cotton polyester core spun yarn made Using ring and air- jet systems. Autext. Res. J., 9 (1): 14-19.

Rizk, M. A. M.; A. M. Azab; E. A. Emesbah; A. A. Hassan and M. A. Sh. Yonis (2016). Technological study on some yarn properties of extra-long staple in Egyptian cotton varieties. AlAzhar. J. Agric. Res., 26: 570-577.

Taher, M. H.; A. Bechir; H. Mohamed and S. Faouzi (2009). Influence of spinning parameters and recovered fibers from cotton waste on the uniformity and hairiness of rotor spun yarn. J. Eng., Fibers \& Fabrics, 4 (3): 36-44.

Tolba, F. S. A. (2017). Production of low priced, medium and coarse yarns using rotor spinning system. M. Sc. Thesis, Fac. of Agric., Benha Univ., Egypt.

Ureyen, M. E. and H. Kadogla (2007). The prediction of cotton ring yarn properties AFIS fiber properties by using linear regression models. Fibers \& Textiles Eastern Europe, 15 (4): 63-71. 
تأثير بعض الخلطات التجارية بين القطن المستورد وأقطان الوجه القبلي على الصفات التكنولوجية

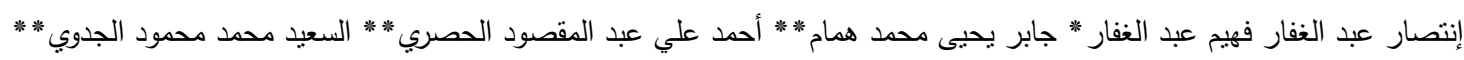

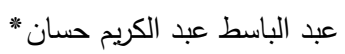

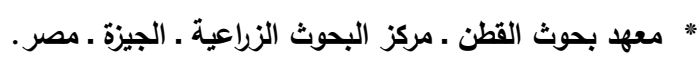

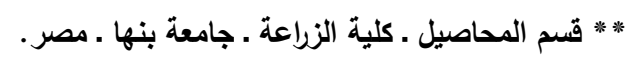

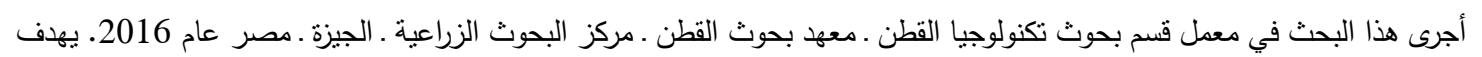

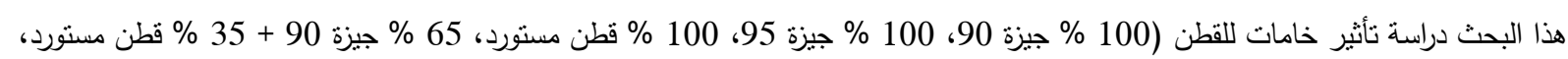

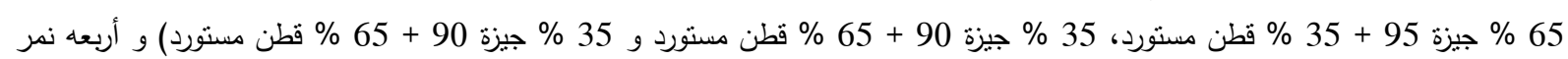

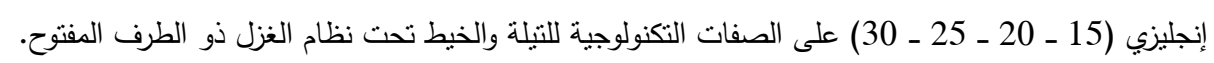
ويمكن تلخيص أهم النتائج فيما يلي: أثنارت النتائج أن الإختلافات بين خامات التيات القطن السبعة تحت الدراسة كانت معنوية في معظم الصفات التكنولوجية للتيلة والخيط الددروسة.

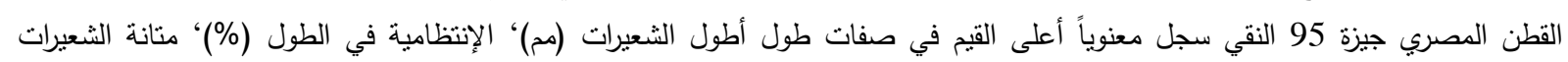

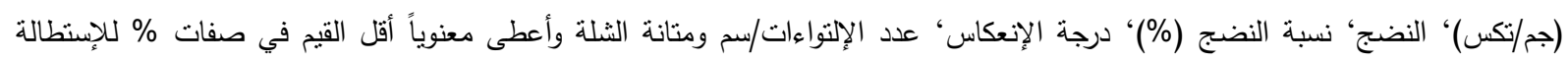

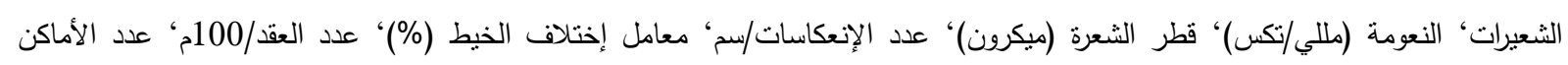

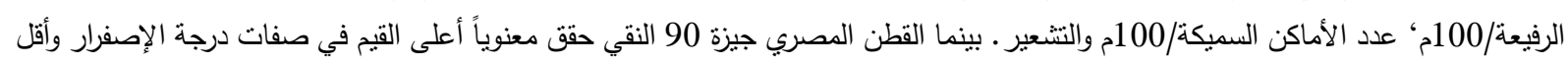

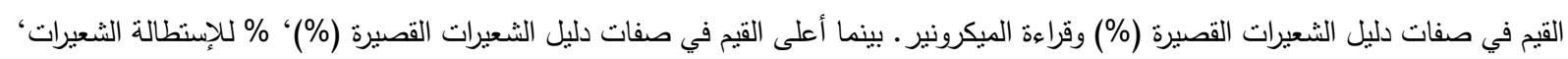

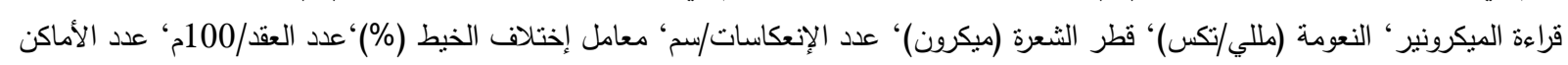

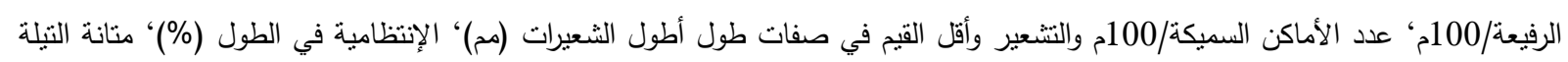

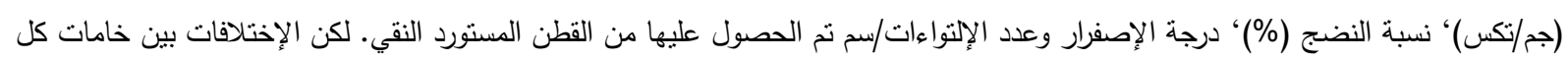

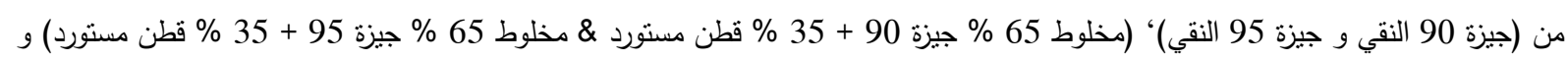

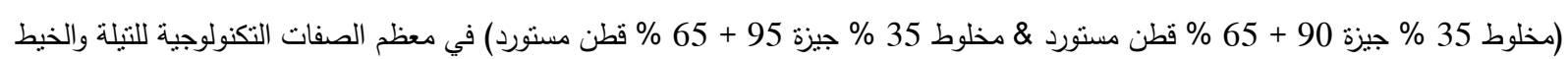

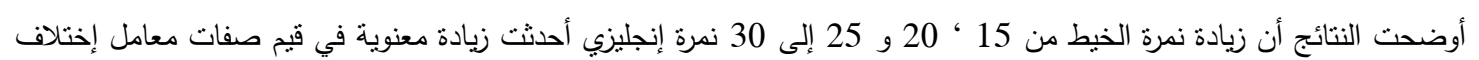

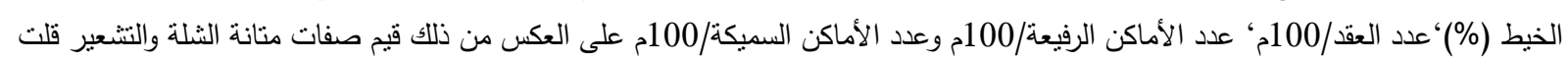

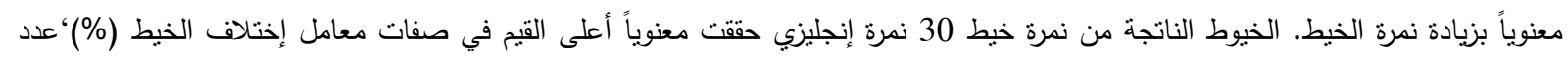

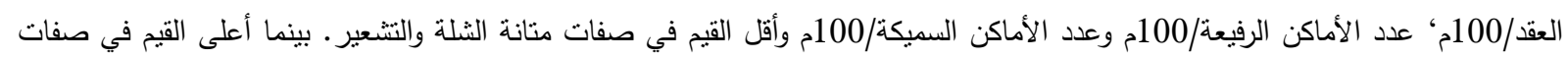

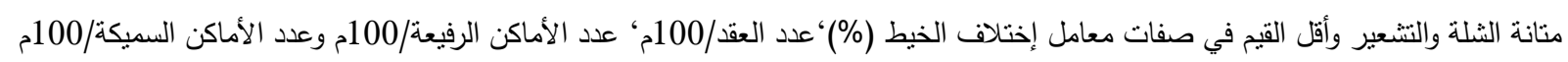

تم الحصول عليهم من الخيوط الناتجة من نمرة خيط 15 نمرة إنجليزي.

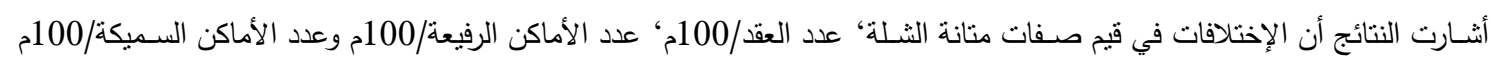

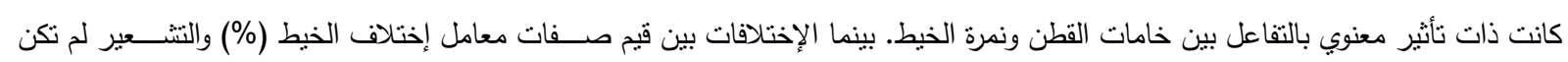

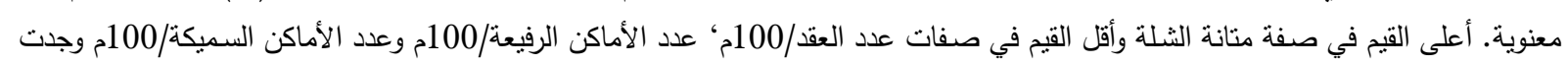

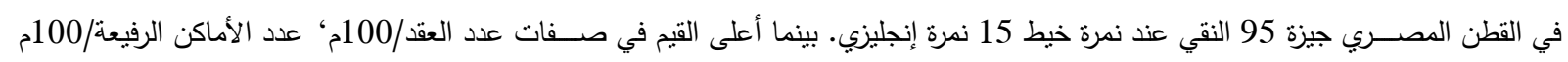

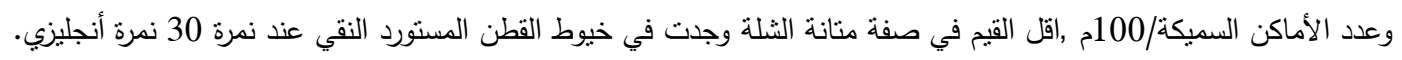

